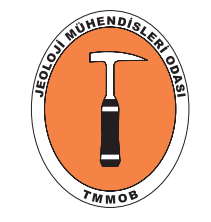

\author{
Türkiye Jeoloji Bülteni \\ Geological Bulletin of Turkey \\ 60 (2017) 209-221 \\ http://tjb.jmo.org.tr
}

\title{
A Comparative Study on Computing Horizontal Derivatives of Gravity Data for Geological Contact Mapping
}

Jeolojik Dokanak Haritalama İçin Gravite Verilerinin Yatay Türevlerinin Hesaplanması Üzerine

Karşılaştırmalı Bir Çalışma

\section{Yunus Levent Ekinci ${ }^{1,2}$}

\author{
${ }^{1}$ Bitlis Eren University, Faculty of Sciences and Arts, Dept. of Archaeology, \\ TR-13000, Bitlis-Turkey \\ ${ }^{2}$ Bitlis Eren University, Career Research and Application Center, TR-13000, Bitlis-Turkey
}

Geliş/Received : 19.01.2017 • Düzeltilmiş Metin Geliş/Revised Manuscript Received : 22.02.2017 • Kabul/Accepted : 27.02.2017 • Bask1/Printed : 01.04 .2017 Araştırma Makalesi/Research Article Türkije Jeol. Bül. / Geol. Bull. Turkey

\begin{abstract}
Computations of $x$ - and y-components of the horizontal derivatives (gradients) from an anomaly grid (with $\mathrm{x}$ - and $\mathrm{y}$-axes directed east and north, respectively) still take an important place in potential field data-processing techniques. These techniques may successfully bring out some significant subtle details that are masked in the anomaly maps. Particularly abrupt lateral changes in densities and magnetizations effectively aid geological mapping and these changes may be traced by some derivative-based techniques without specifying any prior information about the nature of the potential field source bodies. Hence derivative-based techniques are regularly used in the visual interpretation of potential field anomalies. It is well known that computation of horizontal derivatives can be performed through either fast Fourier transform (i.e. in wave number domain) or simple finite-difference equations (i.e. in space domain) to outline the geological source boundaries (edges). Numerous studies including the use of either one have been recorded in the literature so far. In this study, comprehensive comparisons of the solutions obtained from those techniques have been made using both synthetically produced and real gravity data sets. Synthetic applications have been performed using both noise-free and noisy gravity data sets for two different depth-to-source scenarios. Thus not only the signal-to-noise ratios but also the depth-to-source conditions have been analyzed to test the performance of those approaches. Additionally, a real data experiment has been achieved using regional Bouguer gravity anomalies from a portion of a well-known geological setting, the Aegean Graben System (Western Anatolia, Turkey).
\end{abstract}

Key Words: Fast Fourier transform, Finite-differences, First-order horizontal derivatives, Geological contact mapping, Gravity anomalies.

Öz: Potansiyel alan verilerinin işlenmesinde belirti gridinden ( $x$-ve y-eksenleri doğu ve kuzey yönelimli olacak şekilde) yatay türevlerin $x$-ve y-bileşenlerinin hesaplanmasl günümüzde de önemli bir yer tutar. Bu işlemlerle belirti haritalarında ilk bakışta gözlenemeyen önemli detaylar belirlenebilir. En önemlisi ise yoğunluk ve manyetizasyondaki ani yatay değiş̧imlerin ortaya konulmasının jeolojik haritalamaya yardımcı olabileceğidir. Bu değişimler, potansiyel alan kaynak yapılarının doğası hakkında bir ön bilgiye ihtiyaç duymadan türev tabanlı tekniklerle belirlenebilmektedir. Bu nedenle türev tabanlı teknikler potansiyel alan belirtilerinin görsel yorumlanmasinda düzenli olarak kullanılmaktadır. Yatay türevlerin jeolojik kaynak yapı sınırlarının belirlenmesi amacıyla hesaplanması genelde hızlı Fourier dönüşümü (dalga sayısı ortamında) veya basit sonlu-farklar (uzay ortamında) eşitlikleri ile gerçekleştirilebilmektedir. Literatürde bu tekniklerin herhangi biri ile yapılmış sayısız çalışma bulunmaktadır. Bu çalışmada ise, hem sentetik hem de gerçek gravite verilerine her iki tekniğin uygulanmasılyla elde edilmiş çözümler kapsamlı bir şekilde kıyaslanmıştır. Sentetik uygulamalar farklı derinlik senaryolart ile gürültüsüz ve gürültülü veri kullanarak gerçekleştirilmiştir. Böylece her iki tekniğin başarısı, sadece sinyal-gürültü oranında değil aynı zamanda 
yapı derinliği değişimlerinde de sınanmıştır. Ayrıca, Ege Graben Sistemi (Batı Anadolu, Türkiye) gibi iyi bilinen bir jeolojik ortamının bir kısmana ait gravite verilerinin kullanımı ile gerçek veri uygulamaları da yapılmıştır.

Anahtar Kelimeler: Birinci dereceden yatay türevler, Gravite belirtileri, Hızlı Fourier dönüşümü, Jeolojik dokanak haritalama, Sonlu-farklar.

\section{INTRODUCTION}

Computations of directional derivatives of potential field anomalies in both horizontal and vertical directions are still one of the main data-processing and interpretation techniques for geological contact mapping. Edge detecting techniques are generally based on the position of extreme or zero points using directional derivatives and their various combinations (Wanyin et al. 2009). These techniques may describe lateral variations in lithology and yield useful information on structural systems and deformation styles (Zhang et al. 2011). Thus, they are commonly used in the visual interpretation of potential field anomaly maps. The main geological bodies, subtle geological features, geological contacts, geological structures and alignments, and also textural information about geological domains can be described through these techniques (Boschetti 2005). Therefore accurate computation of directional derivatives of potential field data is essential for data-processing and also in data-based interpretation (Roy 2013).

Numerous derivative-based data-processing techniques are frequently used as edge detecting tools such as total horizontal derivatives (Cordell and Grauch 1982, 1985), boundary analysis (Blakely and Simpson 1986), analytic signal amplitude (Roest et al. 1992), tilt angle (Miller and Singh 1994), enhanced horizontal derivative method (Fedi and Florio 2001), total horizontal derivative of the tilt angle (Verduzco et al. 2004), theta map (Wijns et al. 2005), local phase (Cooper and Cowan 2006), normalized standard deviations (Cooper and Cowan 2008), tilt angle derivatives (Salem et al 2008), terracing potential field data (Cooper and Cowan 2009), profile curvature (Cooper and Cowan 2011; Ekinci et al. 2013, 2014, Ekinci and Yiğitbaş 2015), optimized detection filters (Li et al. 2014), eigenvalue analysis of gravity gradient tensor (Zuo and $\mathrm{Hu}$ 2015), improved curvature gravity gradient tensor with principal component analysis (Wang et al. 2015), horizontal directional theta method (Yuan et al. 2016). In all these image enhancement techniques mentioned above, first-order horizontal derivatives in both $\mathrm{x}$ - (east) and y-directions (north) are used. Abrupt lateral changes in densities and magnetizations effectively help geological mapping and these changes may be determined by derivative-based techniques without a prior information about the nature of the causative geological sources. Thus the directional derivatives of potential field data and the products thereof play a significant role in anomaly enhancement (Roy 2013). Computation of horizontal derivatives is deployed fast and easy even using large potential field data sets. Firstorder horizontal derivatives of potential field anomalies are commonly obtained through fast Fourier transform (FFT) or finite-differences (FD) equations.

FFT, a spectral domain technique, is known to be efficient in computing directional derivatives. However, since the technique is sensitive to the noise content in the data, it may be flawed in some cases in computing derivatives (Cooper 2002; Wang 2008). On the other hand, because the differentiation is an ill-posed problem, small errors and deviations in the observations may cause large errors in the derivatives when using simple FD techniques as well (Menke 1984; Li and Ma 2013). It is clear that both techniques may have some drawbacks, and they may encounter problems when dealing with data containing noise content. In this study, therefore, the responses of those techniques were tested and compared using both synthetically produced and real gravity data sets. Both noise-free and noisy gravity anomalies 
were produced for the synthetic simulations. Real data applications were carried out using a portion of regional Bouguer gravity anomalies of the wellknown Aegean graben system (western Anatolia, Turkey). GMINTERP software package (Ekinci 2010; Ekinci and Yiğitbaş 2012, 2015) was used for the simulations presented in the following sections.

\section{METHODOLOGY}

The steepest total horizontal derivative (THD) of a gravity anomaly due to a tabular source tends to overlie the edges of the source body (Blakely 1996). The magnitude of the THDs is defined by

$$
T H D(x, y)=\left[\left(\frac{\partial \Delta g}{\partial x}\right)^{2}+\left(\frac{\partial \Delta g}{\partial y}\right)^{2}\right]^{1 / 2}
$$

where $\Delta \mathrm{g}$ is the gravity anomaly, $\Delta \mathrm{x}$ and $\Delta \mathrm{y}$ are the first-order horizontal derivatives with respect to $\mathrm{x}$ - (east) and $\mathrm{y}$ - (north) directions, respectively. Using the simple FD approaches first-order horizontal derivatives are easily estimated (Blakely 1995). If the discrete measurements are carried out at uniform sample intervals, the horizontal derivatives of observed gravity data at any point are approximated by the following equations (Blakely 1995)

$$
\begin{aligned}
& \frac{\partial \Delta g(x, y)}{\partial x} \approx \frac{\Delta g_{i+1, j}-\Delta g_{i-1, j}}{2 \Delta x} \\
& \frac{\partial \Delta g(x, y)}{\partial y} \approx \frac{\Delta g_{i, j+1}-\Delta g_{i, j-1}}{2 \Delta y}
\end{aligned}
$$

where $i$ and $j$ represent the discrete values of $\Delta \mathrm{g}(\mathrm{x}, \mathrm{y})$ on the observation plane at uniform sample intervals $\Delta \mathrm{x}$ and $\Delta \mathrm{y}$ Additionally, as originally described by Pedersen (1989), firstorder horizontal derivatives can be obtained in wavenumber domain using FFT. According to the differentiation theorem they are given by (Blakely 1995)

$$
\begin{aligned}
& F\left[\frac{\partial \Delta g}{\partial x}\right]=\left(i k_{x}\right) F[\Delta g] \\
& F\left[\frac{\partial \Delta g}{\partial y}\right]=\left(i k_{y}\right) F[\Delta g]
\end{aligned}
$$

where $i k_{x}$ and $i k_{y}$ are the filters that make the transform on a horizontal surface into first-order horizontal derivatives, and $F$ represents the FFT.

For the synthetic simulations, rectangular prisms were considered to approximate a volume of mass. The gravitational attraction of a single rectangular prism is easily computed by integration over the limits of the prism. A rectangular prism with uniform density has a vertical attraction at the origin that is given by following equation (Blakely, 1995)

$$
g=\gamma \rho \int_{z 1}^{z 2} \int_{y 1}^{y 2} \int_{x 1}^{x 2} \frac{z^{\prime}}{\left[x^{\prime 2}+y^{\prime 2}+z^{\prime 2}\right]^{3 / 2}} d x^{\prime} d y^{\prime} d z^{\prime}
$$

where $\gamma$ is the gravitational constant and $\rho$ denotes the density contrast. The derivation of the preceding integral can be provided for the procedure (Plouff 1976), that is,

$$
\begin{aligned}
g= & \gamma \rho \sum_{i=1}^{2} \sum_{j=1}^{2} \sum_{k=1}^{2} \mu i j k\left[z_{k} \arctan \frac{x_{i} y_{j}}{z_{k} R i j k}-x_{i} \log \right. \\
& \left.\left(R i j k+y_{j}\right)-y_{j} \log \left(R i j k+x_{i}\right)\right]
\end{aligned}
$$

where

$$
\begin{aligned}
& \text { Rijk }=\left(x_{i}^{2}+y_{j}^{2}+z_{k}^{2}\right)^{1 / 2} \\
& \mu i j k=(-1)^{i}(-1)^{j}(-1)^{k}
\end{aligned}
$$




\section{SIMULATIONS}

\section{Tests with Synthetic Data}

The gravity response of vertical-sided three prisms (Figure 1a) was generated for the test simulations via Equation 7. A $0.25 \mathrm{~km} \times 0.25 \mathrm{~km}$ grid interval was used for 3D forward modeling. The model parameters of the causative prismatic bodies are given in Table 1. Figures $2 \mathrm{a}$ and $\mathrm{b}$ demonstrate the obtained THD image maps from the application of FFT and FD, respectively. Note that FFT assumes that a grid is periodic and thus it repeats itself infinitely many times in all horizontal directions, and this behavior mostly generates unwanted edge effects if the edges of the data grid do not meet smoothly with their repetitive neighbors (Blakely 1995). Thus, in this study, to reduce the possible discontinuities at the edges, the size of data grid was augmented to the next higher power of 2 by adding artificial data bands to the east and north edges of the data grid prior to the FFT. The added extra data bands were removed at the end of the operation as suggested previously by Ekinci and Yiğitbaş $(2012,2015)$.

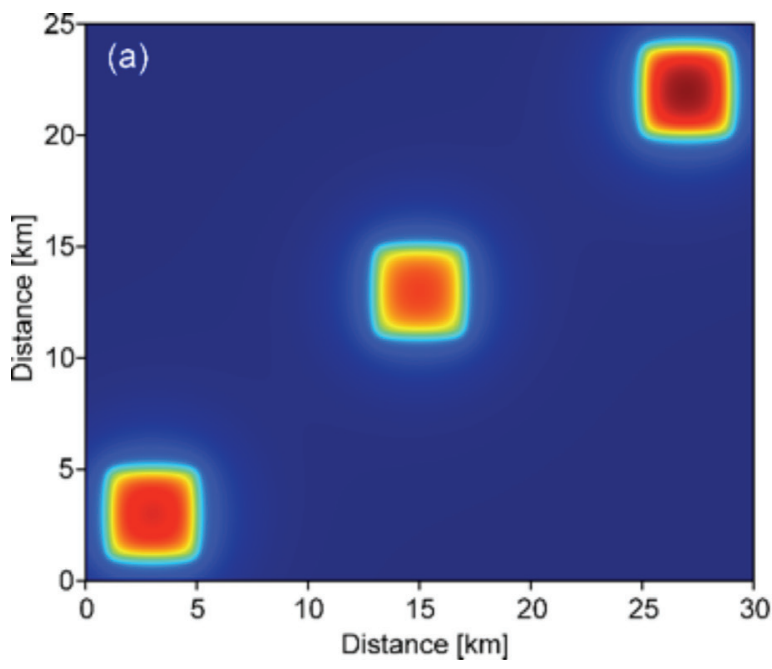

It is clearly seen that both techniques produced almost identical anomaly maps (Figures $2 \mathrm{a}$ and $\mathrm{b}$ ). Amplitude variations in both images exhibited a sharp transition in the amplitudes from the edges towards the centers of the model bodies. Horizontal boundaries of the prismatic bodies were successfully defined by high amplitudes. For the second synthetic example, the depths of the prismatic bodies were increased without changing the thicknesses (Table 2) to see the efficiency of the techniques against to the depthto-source changes. The gravity response of the deeper source bodies is shown in Figure 1b. Since the depths of the bodies were increased, a lower amplitude (resolution) image map was obtained as expected. In this instance, although the high amplitude responses gave some clues for the source positions, FFT and FD techniques (Figures $2 \mathrm{c}$ and d) could not produce sharp boundaries for the edges due to low resolution. Additionally, it is worth mentioning here that unlike the FD-derived THD image (Figure 2d), high amplitude responses of the bodies located at the corners of the map plane are slightly blurred in the FFT-derived THD image (Figure 2c).

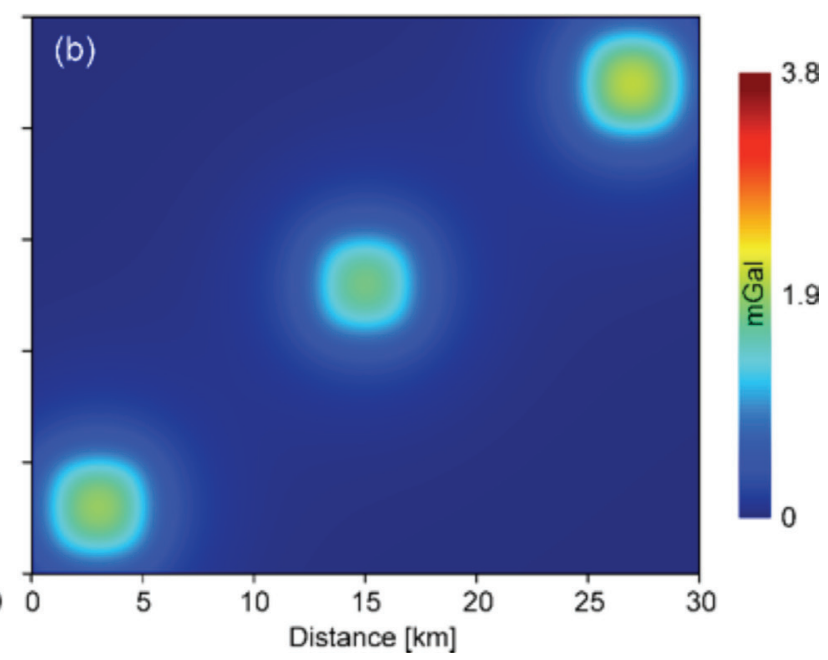

Figure 1. Noise-free synthetic gravity anomalies produced using the model parameters given in a) Table 1, and b) Table 2 .

Şekil 1. a) Tablo 1 ve b) Tablo 2'de verilen model parametreleri kullanılarak üretilen gürültüsüz sentetik gravite belirtileri. 
In the next step to carry out the test studies on noisy data sets anomaly maps given in Figures $1 \mathrm{a}$ and $\mathrm{b}$ were contaminated by adding normally distributed zero-mean pseudo-random numbers with standard deviations of $\pm 0.1 \mathrm{mGal}$ and \pm $0.03 \mathrm{mGal}$, respectively (Figures $3 \mathrm{a}$ and $\mathrm{b}$ ). THD anomaly maps (Figures $4 \mathrm{a}$ and $\mathrm{b}$ ) obtained by the use of both techniques indicate that the edges of the source bodies are clearly improved. However, the effect of the pseudo-random noise is much more enhanced in the FFT-derived THD image map (Figure 4a). Considering the responses of the both operators (Figures $4 \mathrm{c}$ and d) on the amplitude of deeper bodies (Figure 3b) it is obvious that the edges of the source bodies are dominated by low resolution and the noise content is notably increased in FFT-derived THD map (Figure 4c). The synthetic simulations performed using idealized model bodies clearly showed that when the noise level is low or does not exist FFT and FD techniques produce almost the same THD anomaly maps. On the other hand, although both techniques are sensitive to the noise content in the anomalies, FFT amplifies the amplitude of the artificial noise more than does the FD technique.
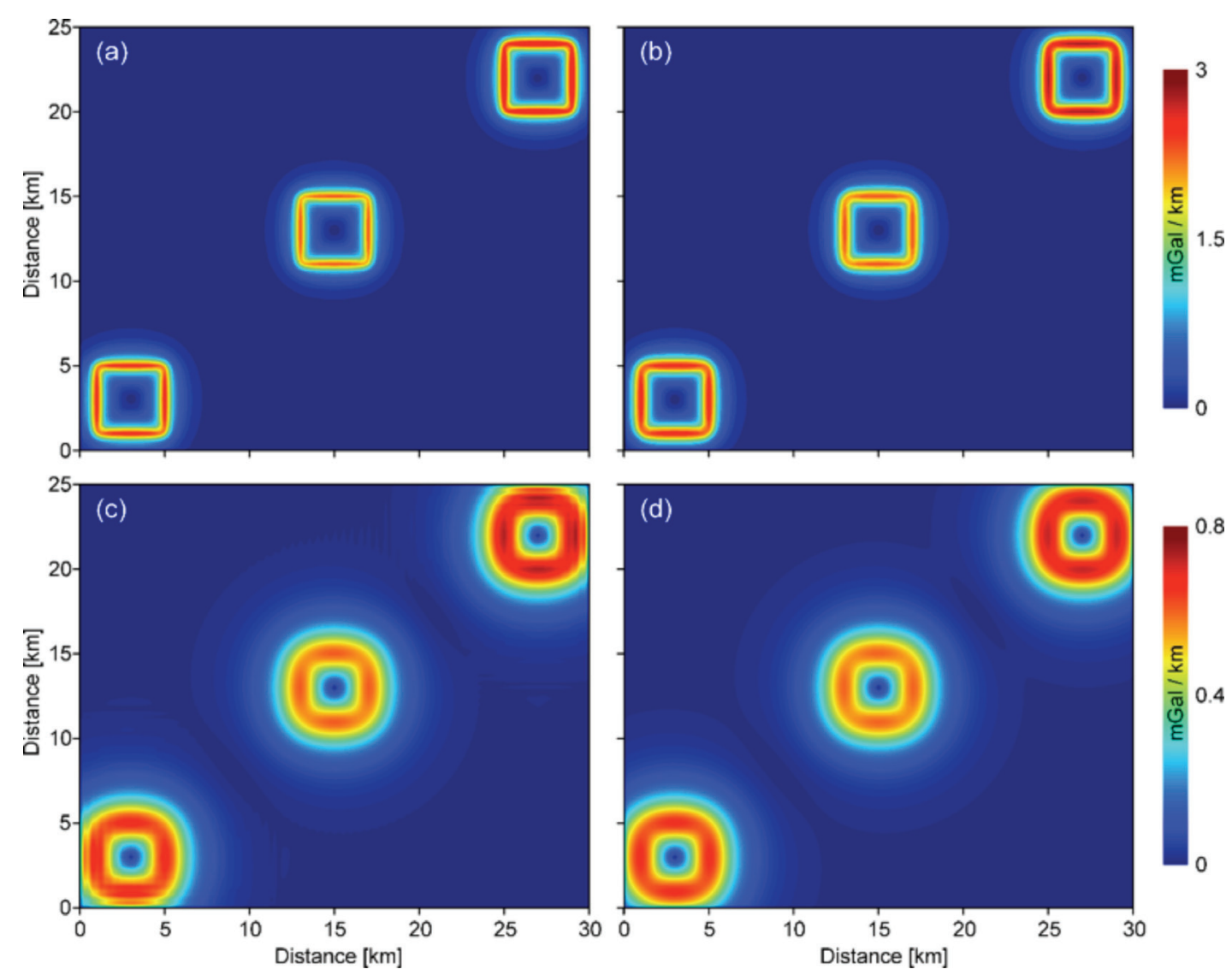

Figure 2. Obtained THD images of a) Figure 1a through FFT, b) Figure 1a through FD, c) Figure 1b through FFT and d) Figure $1 b$ through FD.

Şekil 2. a) HFD kullanarak Şekil 1a'dan, b) SF kullanarak Şekil 1a'dan, c) HFD kullanarak Şekil 1b'den ve d) SF kullanarak Şekil 1b'den elde edilen TYT görüntü haritaları. 

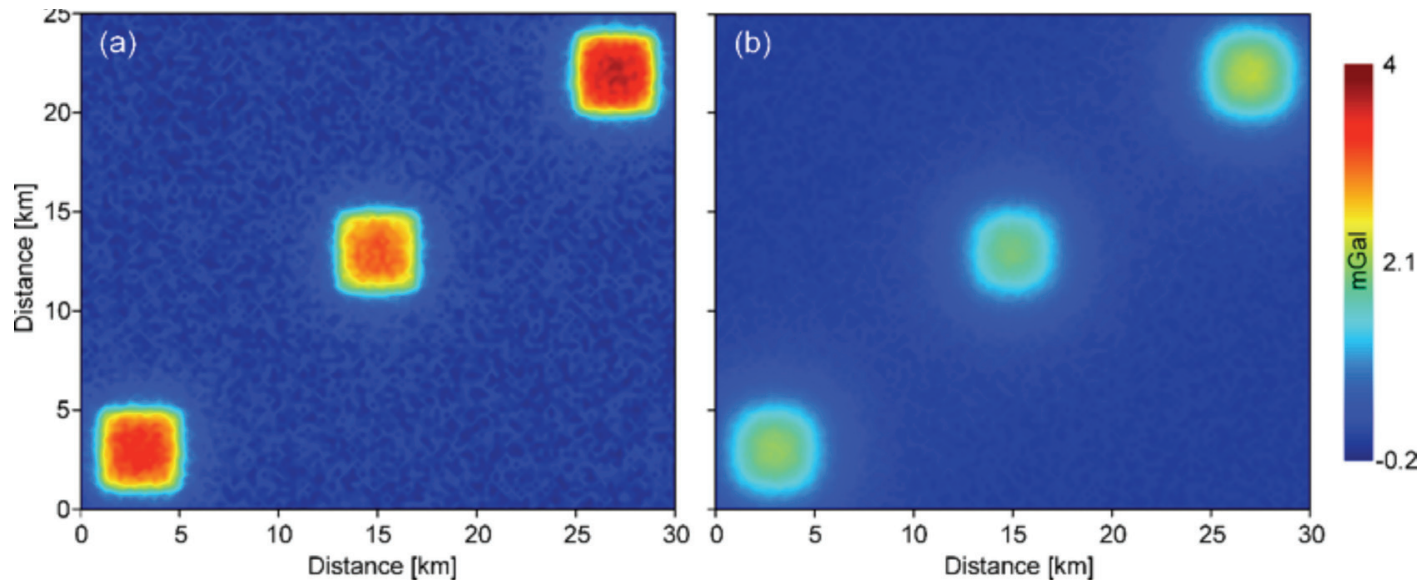

Figure 3. Synthetic gravity anomalies produced using some artificial noise content and the model parameters given in a) Table 1, and b) Table 2.

Şekil 3. a) Tablo 1 ve b) Tablo 2' de verilen model parametreleri ve bir miktar yapay gürültü kullanılarak üretilen sentetik gravite belirtileri.
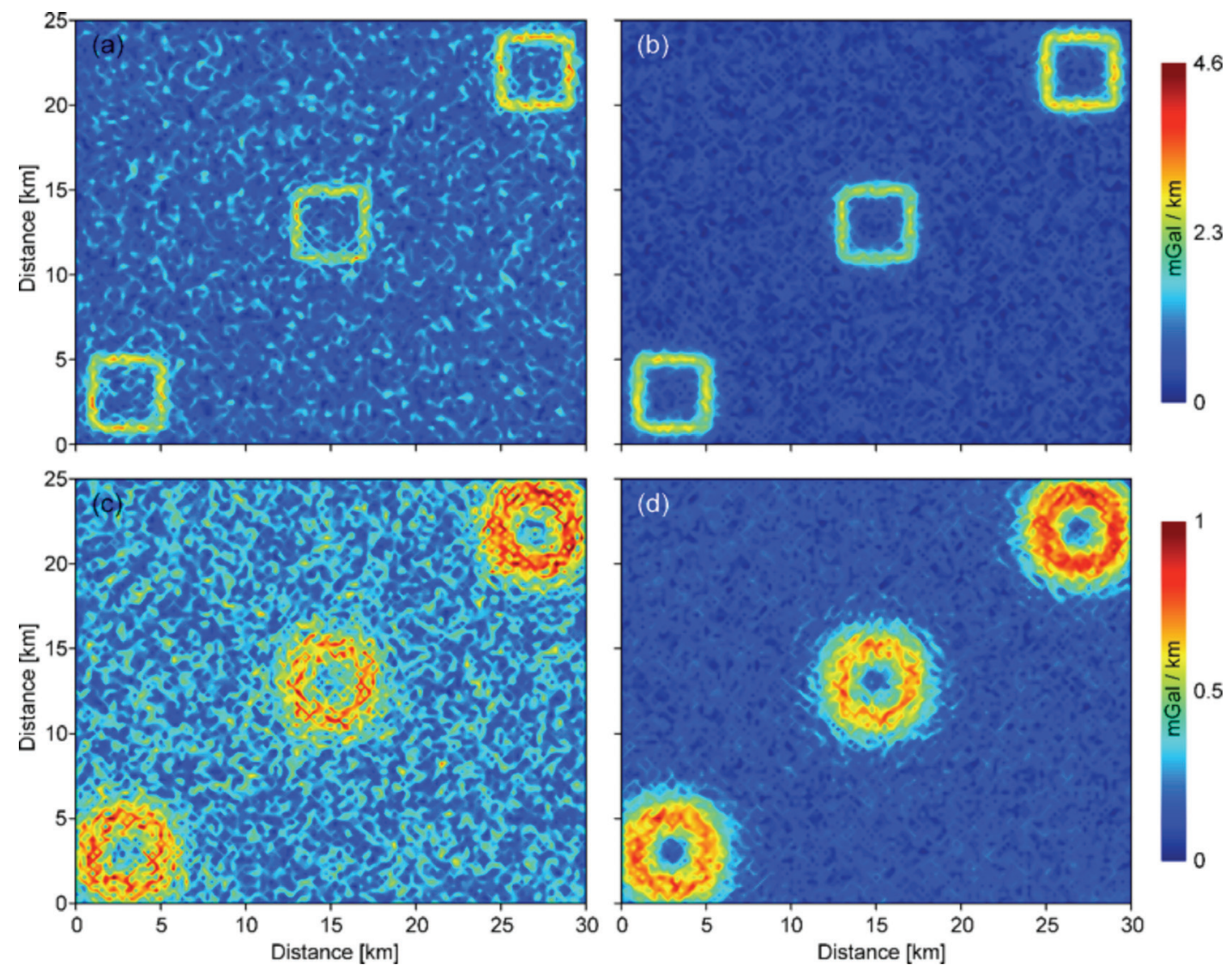

Figure 4. Obtained THD images maps of a) Figure 3a through FFT, b) Figure 3a through FD, c) Figure 3b through FFT and d) Figure $3 b$ through FD.

Şekil 4. a) HFD kullanarak Şekil 3a'dan, b) SF kullanarak Şekil 3a'dan, c) HFD kullanarak Şekil 3b'den ve d) SF kullanarak Şekil 3b'den elde edilen TYT görüntü haritalart. 
Table 1. Model parameters of three prismatic bodies used for the first synthetic application.

Çizelge 1. İlk sentetik uygulama için kullanılan üç prizmatik yapının model parametreleri.

\begin{tabular}{llllllll}
\hline & \multicolumn{7}{c}{ Model parameters } \\
\cline { 2 - 7 } Body number & $\mathrm{x} 1(\mathrm{~km})$ & $\mathrm{x} 2(\mathrm{~km})$ & $\mathrm{y} 1(\mathrm{~km})$ & $\mathrm{y} 2(\mathrm{~km})$ & $\mathrm{h} 1(\mathrm{~km})$ & $\mathrm{h} 2(\mathrm{~km})$ & $\mathrm{rho}\left(\mathrm{g} \mathrm{cm}^{-3}\right)$ \\
\hline 1 & 25 & 29 & 20 & 24 & 0.1 & 1.1 & 0.12 \\
2 & 1 & 5 & 1 & 5 & 0.1 & 1.1 & 0.11 \\
3 & 13 & 17 & 11 & 15 & 0.1 & 1.1 & 0.10 \\
\hline
\end{tabular}

Table 2. Model parameters of three prismatic bodies used for the second synthetic application.

Çizelge 2. İkinci sentetik uygulama için kullanılan üç prizmatik yapının model parametreleri.

\begin{tabular}{llllllll}
\hline & \multicolumn{7}{c}{ Model parameters } \\
\cline { 2 - 7 } Body number & $\mathrm{x} 1(\mathrm{~km})$ & $\mathrm{x} 2(\mathrm{~km})$ & $\mathrm{y} 1(\mathrm{~km})$ & $\mathrm{y} 2(\mathrm{~km})$ & $\mathrm{h} 1(\mathrm{~km})$ & $\mathrm{h} 2(\mathrm{~km})$ & $\mathrm{rho}\left(\mathrm{g} \mathrm{cm}^{-3}\right)$ \\
\hline 1 & 25 & 29 & 20 & 24 & 1.1 & 2.1 & 0.12 \\
2 & 1 & 5 & 1 & 5 & 1.1 & 2.1 & 0.11 \\
3 & 13 & 17 & 11 & 15 & 1.1 & 2.1 & 0.10 \\
\hline
\end{tabular}

\section{Test with Real Data}

The test area considered for the real data example is a well-known geological setting located at the Aegean Graben System (Western Anatolia, Turkey), and it covers an area of $11200 \mathrm{~km}^{2}$ (Figure 5a). Sharp topography in the area is due to young horst-graben geomorphology (Figure 5b). In the study area, NE-SW trending basins (GD: Gördes Basin, DB: Demirci Basin and SB: Selendi Basin) are seismically active regions and they are bounded by active faults (Figure 5c). Through the GDG (Gediz Graben) the footwall of the detachment faults consists of different lithologies belonging to metamorphic rocks of the Menderes Massif (Ekinci et al. 2013), described as Pre-Neogene basement here (Figure 5c). The total thickness of sedimentary fill of the GDG reaches up to about $2500 \mathrm{~m}$ (Çiftçi and Bozkurt 2009). The hanging wall of the detachment fault is characterized by a Miocene to Pliocene sedimentary sequence of clastics labeled as Neogene rocks and by Quaternary alluvium (Ekinci et al. 2013).
GB and SB, as NE-SW trending secondary grabens in the north of GDG, are the components of West Anatolia Extensional Province (WAEP). Both GB and SB comprise Neogene rocks (Figure 5c), which were developed through Miocene, and Quaternary. The GB is marked with Quaternary Alluvium and Neogene (Early Miocene) aged basin fills consisting of clastic, lacustrine and tuffaceous rocks which unconformably overlie Pre-Neogene basement including metamorphic rocks of the Menderes Massif and ophiolitic melange, and each of them is cut by intrusive bodies (Purvis and Robertson 2005). The SB developed over the metamorphic basement of the Menderes Massif and ophiolitic melange (Seyitoğlu 1997, Purvis and Robertson 2005), starts with Early Miocene alluvial fan and fluvio-lacustrine sediments and follows with unconformably EarlyMiddle Miocene continental clastics to lacustrine sediments fill (Seyitoğlu 1997). Sedimentary package overlain Early Miocene strata are coeval and intercalated with volcanic rocks (Seyitoğlu 
1997). The youngest one in the succession is unconformable Pliocene-Quaternary sediment and Quaternary Volcanics (Purvis and Robertson 2005).

DB which developed on the Menderes Massif has similar stratigraphy with SB that comprises two main volcano-sedimentary successions (Helvac1 2015). The basin-fill starts with EarlyMiddle Miocene conglomerates of the Kürtköyü formation that pass upwards into the sandstonemudstone alternations of the Yeniköy formation (Helvac1 2015). These units are unconformably overlain, in ascending order, by the Mahmutlar formation, the Demirci formation, and the Sevinçler volcanics that crop out in the northeastern part of the basin (İnci 1984). Strike-slip faults with the normal component are basin-bounding faults of NE-SW trending basins and exhibit an almost straight outcrop pattern. They occur as single or fault segments and juxtapose basement with basin fill (Bozkurt 2003).

The regional Bouguer gravity data of entire Turkey were acquired at approximately 2-5 $\mathrm{km}$ intervals and the whole anomaly map was published by General Directorate of Mineral Research and Exploration of Turkey (MTA 2006) using $2 \mathrm{~km}$ grid spacing. In the regional anomaly map of the studied area shown in Figure 6a, an increasing trend in the anomaly amplitudes towards the west is clearly seen due to the thinning crust (Ekinci et al. 2013). The relatively thick sedimentary deposits of the GDG and the Neogene basins cause to the lowering of gravity amplitudes (Sar1 and Şalk 2002, 2006; Ekinci et al. 2013). $\mathrm{BH}$ (Bozdağ Horst) is characterized by relatively higher gravity amplitudes due to the existence of metamorphic rocks of the Menderes massif as clearly seen from Figure 5c.
Before the computation of THDs, a firstorder polynomial surface including the effects of the horizontal trend and regional background was subtracted from the regional Bouguer anomaly map shown in Figure 6a to obtain the residual anomalies exhibiting the effects of shortest wavelengths. Figure $6 \mathrm{~b}$ shows the residual anomaly map, and it is clearly seen that the increasing trend in gravity amplitudes towards the Aegean Sea was successfully attenuated. Thus a first-order polynomial surface is deemed to be sufficient. Additionally, negative gravity anomalies of the sedimentary deposits of GDG and the basins were noteworthy enhanced (Figure 6b) which allowed for a more accurate comparison. Image maps in Figures $7 \mathrm{a}$ and $\mathrm{b}$ show the performances of FFT and FD techniques, respectively, on producing the THD anomalies. Images indicate that both techniques produced close anomaly patterns. However, when the images are carefully analyzed it is seen that FD-derived THD map yielded a more detailed response. Abrupt lateral changes in densities between GDG and neighboring Neogene rocks produced higher amplitudes in FD-derived THD map (Figure 7b). In order to better understand the performances of those techniques, normalized amplitude THD maps were also produced and they are demonstrated in Figures $7 \mathrm{c}$ and d using the anomalies in Figures $6 a$ and $b$, respectively. High amplitude traces surrounding the GDG are more evident in the FD-based image (Figure 7d). Additionally, some traces of the NE-SW trending normal faults bounding the basins located at the NE part of the study area are obviously observed in Figure $7 d$. On the other hand, the traces of the aforesaid faults could not be followed clearly in Figure 7c. Based on the results of real data example it is worth mentioning here that the superiority of FD technique on the calculation of THDs over FFT technique is evidentiary. 

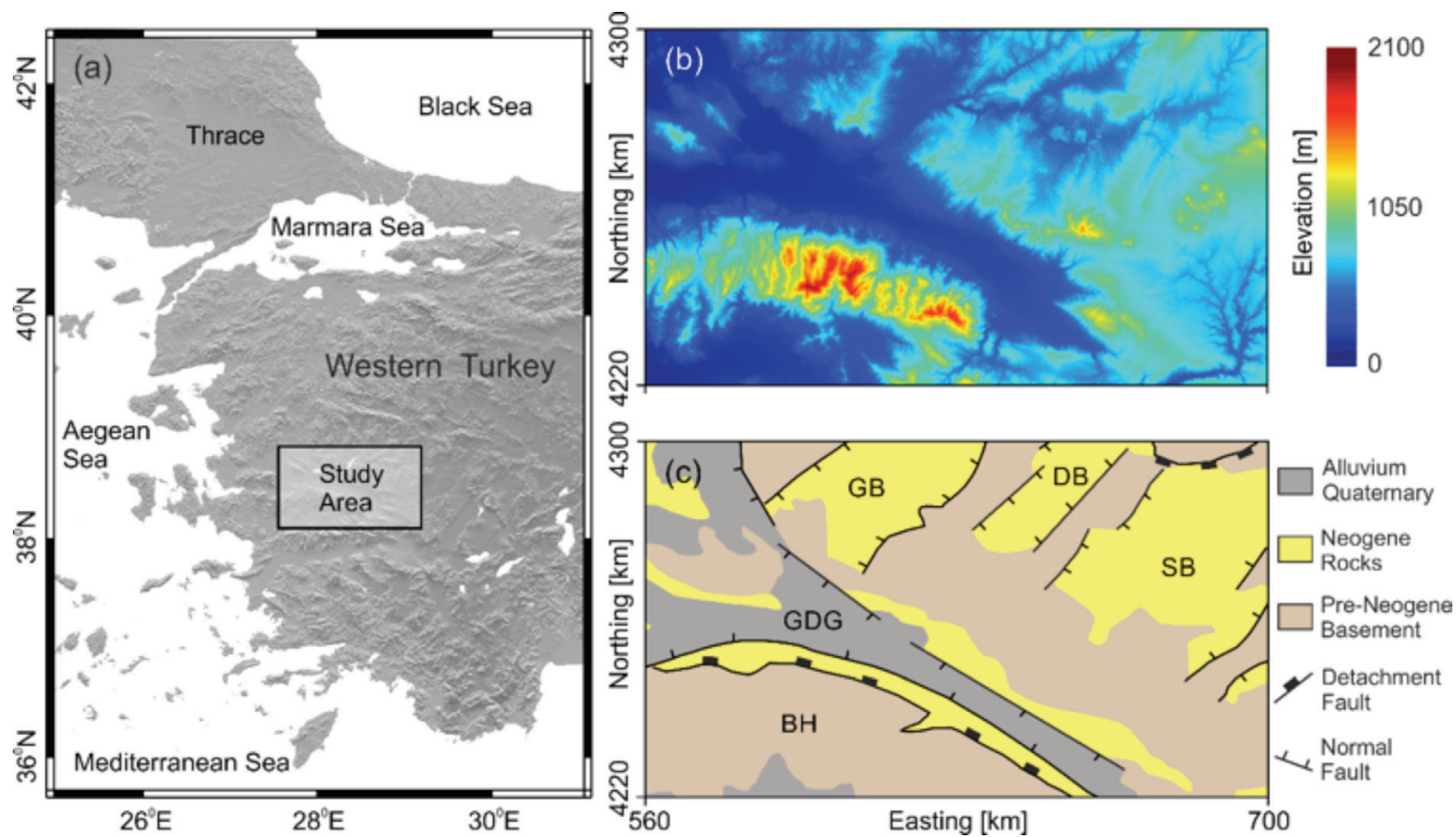

Figure 5. a) Location map, b) Topographic map and c) Geology map of the study area (modified from MTA (2002), Sözbilir et al. (2011) and Ekinci et al. (2013)).

Şekil 5. Çalışma alanının a) Yerbulduru haritası, b) Topografik haritası ve c) Jeoloji haritası (MTA (2002), Sözbilir vd. (2011) ve Ekinci vd. (2013)'den düzenlenmiştir).
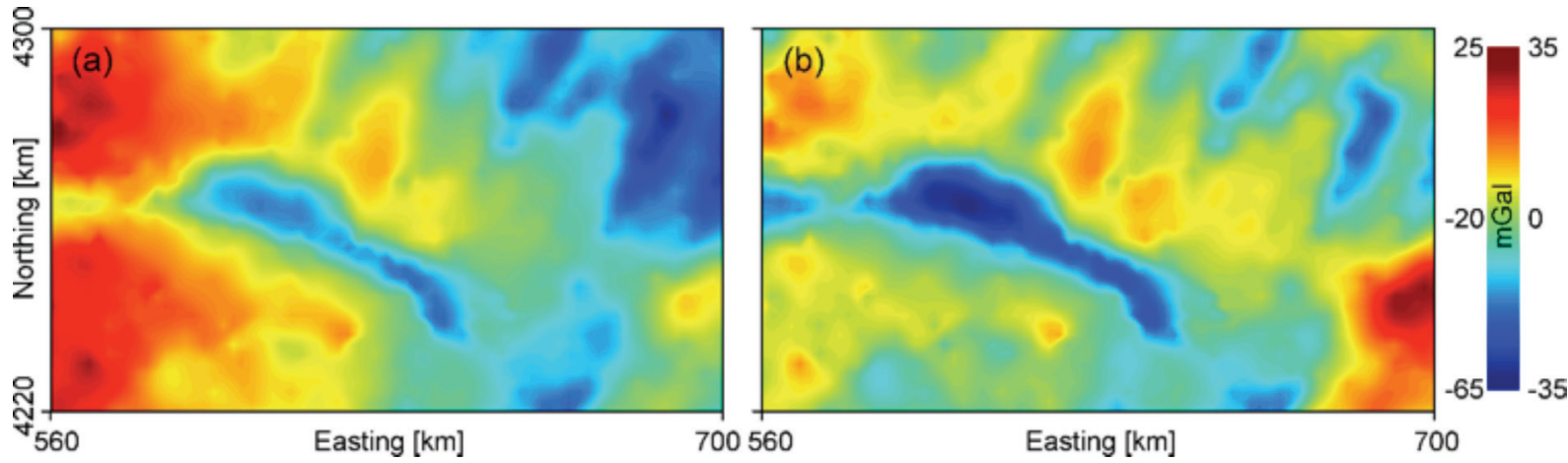

Figure 6. a) Regional and b) Residual gravity anomaly maps of the study area.

Şekil 6. Çalışma alanının a) Rejyonal ve b) Rezidüel gravite belirti haritaları. 


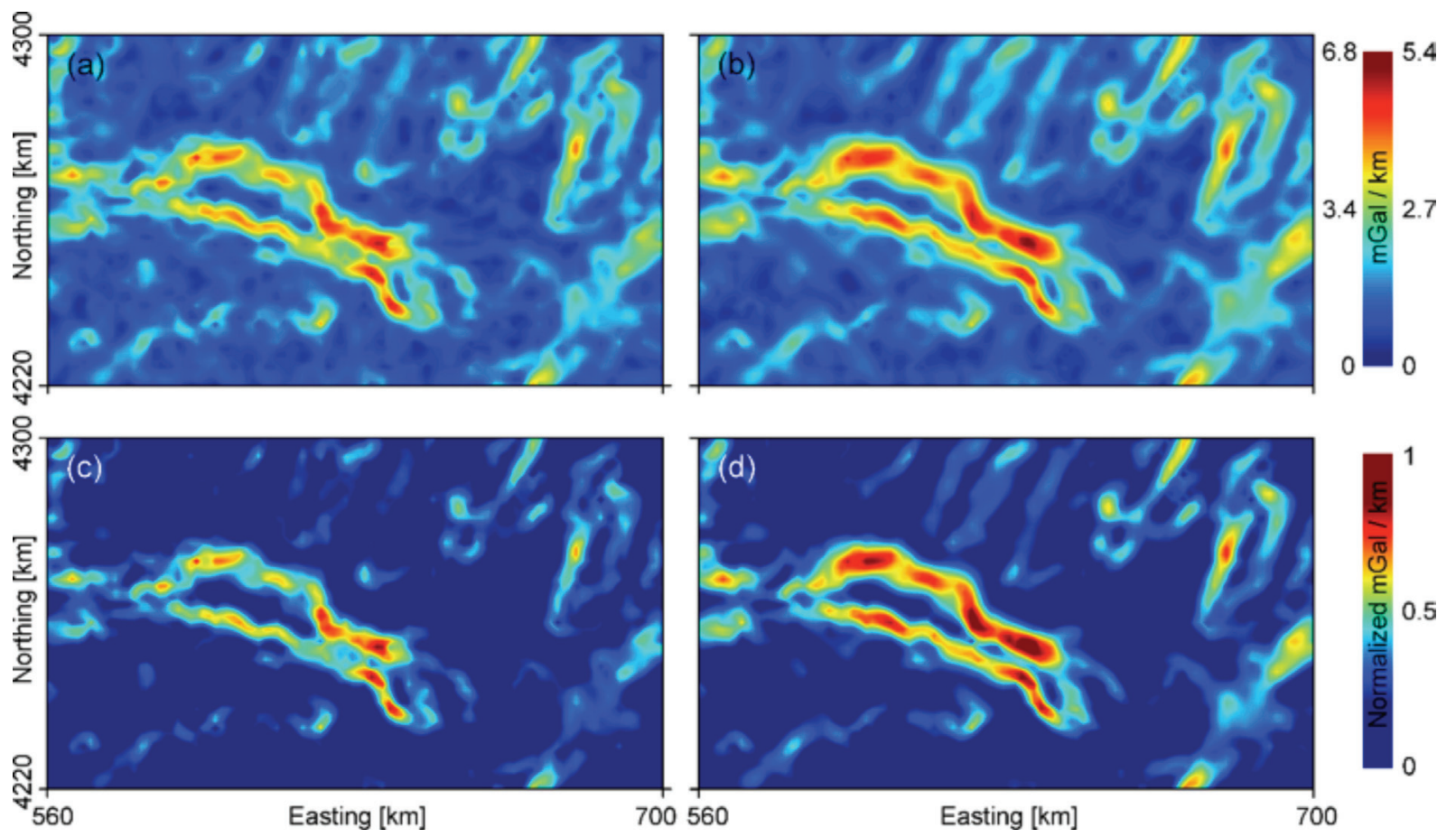

Figure 7. Obtained THD images of a) Figure $6 \mathrm{~b}$ through FFT, b) Figure $6 \mathrm{~b}$ through FD, c) Normalized amplitude maps of Figure 7a and d) Figure 7b.

Şekil 7. a) HFD ve b) SF kullanarak Şekil 6b'den elde edilen TYT görüntü haritalarl, c) Şekil 7a'nın ve d) Şekil $7 b$ 'nin normalize edilmiş genlik haritaları.

\section{CONCLUSIONS}

Acomprehensivestudy comparing the effectiveness of wavenumber domain (i.e. FFT) and space domain (i.e. FD) techniques in computing firstorder horizontal derivatives of two-dimensional gravity data is presented. Through the test studies performed using synthetic anomalies with and without noise content, it was obviously observed that FD-based THD image maps yield more dramatic solutions for the computation of horizontal derivatives. Additionally, the results obtained from the synthetic applications show that the simple difference equations are more robust and effective in enhancing the amplitudes of deeper sources in the existence and the absence of noise content. Real data experiment achieved using regional Bouguer gravity anomalies from a portion of a well-known geological setting, the Aegean graben system (western Anatolia, Turkey), also indicate the advantage of FD technique in producing THD image maps. The locations of the abrupt lateral changes in densities are clearly improved in THD map produced by means of FD technique. Based on the both synthetically produced and real field data experiments FD technique is decided to be more efficient in computing the horizontal derivatives.

\section{ACKNOWLEDGEMENTS}

Thanks are due to Dr. Coşkun Sarı (Dokuz Eylül University) and Dr. Erdinç Yiğitbaş (Çanakkale Onsekiz Mart University) for their suggestions that have contributed to the improvement of the manuscript. 


\section{GENIŞLETILMIŞ ÖZET}

Bilindiği gibi yatay türev hesaplama işlemleri potansiyel alan verilerinde en sik kullanilan veriişlem yöntemlerinden biridir. Belirti haritalarında ilk etapta göze çarpmayan jeolojik çizgisellikler ve dokanaklar türev tabanl bu yöntemlerle belirlenebilmektedir. Özellikle yoğunluk veya manyetizasyondaki ani yatay değişimler jeolojik birim geçişlerini gösterebilmekte ve bu sebeple belirti haritalarındaki çizgisellikler jeolojik haritalamada da fikir vermesi bakımından kullanılmaktadır. Ayrıca kaynak yapının doğası ile ilgili herhangi bir ön bilgiye ihtiyaç duyulmamast, yöntemin hizlı bir şekilde uygulanabilmesine olanak sağlamaktadır. Bu nedenle türev tabanl sinır belirleme algoritmalart potansiyel alan belirtilerinin görsel yorumlanmasinda oldukça yaygın bir biçimde kullanılmaktadır. Birçok kenar belirleme algoritmalarının temelini oluşturan yatay türevler genellikle dalga sayısı ortamında hızlı Fourier dönüşümü (HFD) yardımıyla ya da uzay ortaminda basit sonlu farklar (SF) eşitlikleri ile hesaplanabilmektedir. Bugüne kadar ki yapılan çalışmalarda HFD tekniğinin gürültü içeriğinin yüksek olduğu yerlerde să̆lıklı sonuç üretmediği hakkında yayınlar mevcuttur. Ancak unutulmaması gereken türev hesaplamalarında SF tekniği de gürültüye duyarlıdır. Bu nedenle her iki tekniğin birbirlerine göre olumlu ve olumsuz yanları bu çalışmada araştırılmıştır. Bu amaçla ilk önce teorik olarak üretilen gravite verilerinden yararlanılmış, gürültülü ve gürültüsüz olarak üretilen gravite verilerine neden olan kaynak yap derinlikleri farklı örneklerle farklı alınmış ve hem gürültü içeriğinin hem de kaynak yapı derinliğinin çözümler üzerindeki etkisi değerlendirilmiştir.

Kuramsal çalışmalar sonucunda, yüzeye yakın kaynak yaplların ürettikleri yüksek genlikli gravite belirtilerinden elde edilen toplam yatay türev (TYT) haritalart incelendiğinde HFD ve SF tekniklerinin neredeyse ayn belirtileri ürettiği gözlenmiştir. Ancak, gürültülü gravite verilerinden üretilen TYT haritalarında HFD tekniğinin SF tekniğine göre gürültü içeriğini daha da arttırdı $\breve{g} l$ görülmüş̧ür. Kaynak yapılarının derinliğinin arttırılması ile elde edilen nispeten daha düşük genlikli gravite verilerinden üretilen TYT haritalart incelendiğinde ise yine SF tekniğinin yapı sinırlarına ait daha yüksek çözünürlüklü görüntüler ürettiği ve gürültü içeriğinden daha az etkilendiği ortaya konulmuştur.

Kuramsal uygulamaların ardından gerçek veri uygulaması için Ege Graben Sisteminin bir kısmını kapsayan rejyonal Bouger gravite verileri ele alınmıştır. Seçilen çalışma alanı Gediz Grabeni $(G D G)$ ve tümü KD-GB yönelimli olan Gördes Baseni (GD), Demirci Baseni (DB) ve Selendi Baseni (SB)'ni kapsamaktadir. Uygulamalarda öncelikle gravite verilerinden dalga boyu büyük olan derin etkiler birinci dereceden bir polinom yardımıyla giderilmiş, kısmen dalga boyu küçük olan siğ jeolojik yapıların etkilerini sunan belirti haritası elde edilmiş ve ardından TYT işlemlerine geçilmiştir. Hesaplanan TYT belirti haritalar dikkatli bir şekilde incelenmiş ve kuramsal veri uygulamalarında olduğu gibi arazi verileri ile gerçekleştirilen çalışmalarda da SF tekniğinin daha duyarlı sonuçlar ürettiği gözlenmiştir. Özellikle çalışma alanının KD kısmına düşen yoğunluk değişimlerine yani basenlerin sınırlarını oluşturan faylara ait bazı çizgisellikler SF ile elde edilen TYT haritalarında daha net bir şekilde ortaya konmuştur. Böylece hem kuramsal hem de gerçek arazi çalışmalarından, yatay türevlerin hesaplanmast işlemlerinde SF tekniğinin HFD tekniğine göre daha etkili olduğu belirlenmiştir.

\section{REFERENCES}

Blakely, R.J., 1995. Potential Theory in Gravity and Magnetic Applications. Cambridge: Cambridge University Press.

Blakely, R.J. and Simpson, R.W., 1986. Approximating edge of source bodies from magnetic or gravity anomalies. Geophysics, 51, 1494-1498.

Boschetti, F., 2005. Improved edge detection and noise removal in gravity maps via the use of gravity 
gradients. Journal of Applied Geophysics, 57, 213-25.

Bozkurt, E., 2003. Origin of NE-trending basins in western Turkey. Geodinamica Acta, 16, 61-81.

Cooper, G.R.J., 2002. An improved algorithm for Euler deconvolution of potential field data. Leading Edge, 21, 1197-1198.

Cooper, G.R.J. and Cowan, D.R., 2006. Enhancing potential field data using filters based on the local phase. Computers \& Geosciences, 32, 1585-1591.

Cooper, G.R.J. and Cowan, D.R., 2008. Edge enhancement of potential-field data using normalized statistics. Geophysics, 73, H1-H4.

Cooper, G.R.J. and Cowan, D.R., 2009. Terracing potential field data. Geophysical Prospecting, 57, 1067-1071.

Cooper, G.R.J. and Cowan, D.R., 2011. A generalized derivative operator for potential field data. Geophysical Prospecting, 59, 188-194.

Cordell, L. and Grauch, V.J.S., 1982. Reconciliation of the discrete and integral Fourier transform. Geophysics, 47, 237-243.

Cordell, L. and Grauch, V.J.S., 1985. Mapping basement magnetization zones from aeromagnetic data in the San Juan Basin, New Mexico, In: W.J., Hinze, (ed.), The utility of regional gravity and magnetic anomaly maps: Society Exploration Geophysics, Tulsa, Oklahoma, 181-197.

Çiftçi, N.B. and Bozkurt, E., 2009. Evolution of the Miocene sedimentary fill of the Gediz Graben, SW Turkey. Sedimentary Geology, 216, 49-79.

Ekinci, Y.L., 2010. A Matlab-based interactive data processing and interpretation software package for gravity and magnetic anomalies: GMINTERP, 19th International Geophysical Congress and Exhibition, Ankara, Turkey, 60.

Ekinci, Y.L. and Yiğitbaş, E., 2012. A geophysical approach to the igneous rocks in the Biga Peninsula (NW Turkey) based on airborne magnetic anomalies: Geological implications. Geodinamica Acta, 25, 267-285.

Ekinci, Y.L., Ertekin, C. and Yiğitbaş, E., 2013. On the effectiveness of directional derivative based filters on gravity anomalies for source edge approximation: Synthetic simulations and a case study from the Aegean graben system (western Anatolia, Turkey). Journal of Geophysics and Engineering, 10, 035005.
Ekinci, Y.L., Balkaya, Ç., Şeren, A., Kaya, M.A. and Lightfoot, C.S., 2014. Geomagnetic and geoelectrical prospection for buried archaeological remains on the Upper City of Amorium, a Byzantine city in Midwestern Anatolia, Turkey. Journal of Geophysics and Engineering, 11, 015012 .

Ekinci, Y.L. and Yiğitbaş, E., 2015. Interpretation of gravity anomalies to delineate some structural features of Biga and Gelibolu peninsulas, and their surroundings (north-west Turkey). Geodinamica Acta, 27 (4), 300-319.

Fedi, M. and Florio, G., 2001. Detection of potential fields source boundaries by enhanced horizontal derivative method. Geophysical Prospecting, 49, 40-58.

Helvac1, C., 2015. Geological features of Neogene basins hosting borate deposits: an overview of deposits and future forecast, Turkey. Bulletin of the Mineral Research and Exploration, 151, 169215.

Li, Z.G. and Ma, Z.H., 2014. A new approach for filtering and derivative estimation of noisy signals. Circuits, Systems, and Signal Processing, 33, 589-598.

Li, L., Huang, D., Han, L. and Ma, G., 2014. Optimised edge detection filters in the interpretation of potential field data. Exploration Geophysics, 45, 171-176.

Menke, W., 1984. Geophysical Data Analysis: Discrete Inverse Theory: Academic Press Inc, New York.

Miller, H.G and Singh, V., 1994. Potential field tilt-a new concept for location of potential field sources. Journal of Applied Geophysics, 32, 213-217.

MTA (General Directorate of Mineral Research and Exploration of Turkey), 2002. Geological map of Turkey, MTA Publications scale: 1/500000, Ankara, Turkey.

MTA (General Directorate of Mineral Research and Exploration of Turkey), 2006. Bouguer gravity anomaly map of Turkey, MTA Publications scale: 1/2000000, Ankara, Turkey.

Plouff, D., 1976. Gravity and magnetic fields of polygonal prisms and application to magnetic terrain correction. Geophysics, 41, 727-741.

Purvis, M. and Robertson, A., 2005. Miocene sedimentary evolution of the NE-SW-trending Selendi and Gördeş Basins, W Turkey: implications 
for extensional processes. Sedimentary Geology, 174, 31-62.

Roest, W.R., Verhoef, J. and Pilkington, M., 1992. Magnetic interpretation using the 3-D analytic signal. Geophysics, 57, 116-125.

Roy, I.G., 2013. On computing gradients of potential field data in the space domain. Journal of Geophysics and Engineering, 10, 035007.

Salem, A., Williams, S., Fairhead, D., Smith, R. and Ravat, D., 2008. Interpretation of magnetic data using tilt-angle derivatives. Geophysics, 73, L1L10.

Sarı, C. and Şalk, M., 2002. Analysis of gravity anomalies with hyperbolic density contrast: an application to the gravity data of western Anatolia. Journal of Balkan Geophysical Society, 5, 87-96.

Sarı, C. and Şalk, M., 2006. Sediment thickness of the western Anatolia graben structures determined by $2 \mathrm{D}$ and $3 \mathrm{D}$ analysis using gravity data. Journal of Asian Earth Sciences, 26, 39-48.

Seyitoğlu, G., 1997. Late Cenozoic tectono-sedimentary development of the Selendi and Uşak-Güre basins: a contribution to the discussion on the development of east-west and north trending basins in western Turkey. Geological Magazine, 134, 163-175.

Sözbilir, H., Sarı, B., Uzel, B., Sümer, Ö. and Akkiraz, S., 2011. Tectonic implications of transtensional supradetachment basin development in an extension-parallel transfer zone: the Kocaçay Basin, western Anatolia, Turkey. Basin Research, 23, 423-448.

Verduzco, B., Fairhead, J.D., Green, C.M. and MacKenzie, C., 2004. The meter reader-New insights into magnetic derivatives for structural mapping. The Leading Edge, 23, 116-119.

Wanyin, W., Yu, P. and Zhiyun, Q., 2009. A new edge recognition technology based on the normalized vertical derivative of the total horizontal derivative for potential field data. Applied Geophysics, 6, 226-33.

Wang, Z., Krebes, E.S. and Ravat, D., 2008. High precision potential field and gradient-component transformations and derivative computations using cubic B-splines. Geophysics, 73, I35-I42.

Wang, J., Meng, X.H. and Li, F., 2015. Improved curvature gravity gradient tensor with principal component analysis and its application in edge detection of gravity data. Journal of Applied Geophysics, 118, 106-114.

Wijns, C., Perez, C. and Kowalczyk, P., 2005. Theta map: Edge detection in magnetic data. Geophysics, 70, L39-L43.

Yuan, Y., Gao, J. and Chen L., 2016. Advantages of horizontal directional Theta method to detect the edges of full tensor gravity gradient data. Journal of Applied Geophysics, 130, 53-61.

Zhang, H.L., Tian-You, L. and Yu-Shan, Y., 2011. Calculation of gravity and magnetic source boundaries based on anisotropy normalized variance. Chinese Journal of Geophysics 54, 560 567.

Zuo, B. and Hu, X., 2015. Edge detection of gravity field using eigenvalue analysis of gravity gradient tensor. Journal of Applied Geophysics, 114, 263 270 . 
